\title{
The Advantages of Local Institutions in Improving Disaster- Affected Small Entrepreneurs and Surrounding Society A Study of Paguyuban Kampung Sablon, Wedi Village, Klaten Regency
}

\author{
Syadza Alifa \\ Department of Social Welfare \\ Universitas Indonesia \\ Depok, Indonesia \\ syadza.alifa19@gmail.com
}

\author{
Fentiny Nugroho \\ Department of Social Welfare \\ Universitas Indonesia \\ Depok, Indonesia \\ fentiny2015@gmail.com
}

\begin{abstract}
Paguyuban Kampung Sablon was established after Klaten District was hit by an earthquake that affected the economy of the community, including the convection industry in Pandes Wedi village, and its surroundings. The disaster aroused the spirit to empower the community in Pandes Wedi Village so they established Paguyuban Kampung Sablon which aims to make convection entrepreneurs in Pandes Wedi Village are able to recover the economic condition after the disaster. The method of data collection of this research is the study of literature, study of documents, observation, in-depth interviews and focus group discussions. This study argues that disaster management program is often considered ineffective to restore the economic conditions of disaster affected community, however the presence of a local institution as community-based self-help that directly initiated by the local community is able to improve and restore the socio-economic conditions of disaster-affected entrepreneur and surrounded society.
\end{abstract}

Keywords: disaster; local institution; entrepreneurship

\section{INTRODUCTION}

One of the most important post-disaster recovery and empowerment efforts is to increase the level of community selfreliance through empowerment in local institutions or local organizations. Implementation of empowerment in local communities is manifested in various forms of collective actions in order to make changes in living conditions. Therefore, at the local community level the most important instrument in the empowerment process is the presence of local institutions.

One of the empowerment through local institutions or local organizations conducted in disaster area is economic empowerment of society in Paguyuban Kampung Sablon, Klaten, Central Java. Klaten District is one of the areas affected by the earthquake disaster on May 27, 2006, measuring 5.9 on the Ricter Scale in Yogyakarta. The earthquake disaster in Klaten region caused the loss of morale and material and socio-economic order of earthquake victims in Klaten. The majority of people owning and working in small convection home industries suffered great loss in both capital and business resources. Despite of that, small entrepreneurs of convection in Wedi village didn't easily felt despair and collapse, instead they began to rise again in convection business field by establishing convection business community.

Research on the role of institutions in empowering communities after the disaster has been conducted previously. The research that discussed about economic empowerment through entrepreneurship and skill training was conducted by Amry Hari Besar, Moch Yuhdi Batubara, and Margono with its title "Empowerment of Lapindo Mudflow Victims in Ensuring Survival of Live in Mindi Kecamatan Porong Village, Sidoarjo Regency". This study shows that government efforts to empower community through skills programs are often fruitless because only few people will survive and apply the knowledge after being trained. This is because the empowerment program through the improvement of skills and entrepreneurship's characteristic is top-down so it more likely has a less comprehend of the real needs of society in the field of social economy.

Another study of the KDP entrepreneurship program (Kecamatan Development Program) conducted by Sukmaniar under the title "Effectiveness of Community Empowerment in the Management of Kecamatan Development Program (PPK) in Lhoknga Sub-district, Aceh Besar District" shows that in general, community empowerment in post-tsunami KDP management in Kecamatan Lhoknga in attempt to improve the condition of community empowerment is less effective. The main cause of its less effectiveness is typology of community empowerment.

From the previous studies, there has been no research that specifically discussed the process of empowerment through local institutions made by local communities in disaster-affected areas because these institutions are generally formed by government or NGOs. In previous studies, economic empowerment programs were mostly carried out by the government, not on the initiative of the community itself. Therefore, in some previous studies, economic empowerment programs for disaster-affected communities were deemed ineffective in restoring economic conditions and creating community economic independence.

Corresponding authors: Fentiny Nugroho 
Derived from the facts, this study formulated the problem: How to benefit the presence of local institutions for improving the lives of disaster-affected small entrepreneurs and surrounded community?

\section{RESEARCH METHOD}

This research uses a qualitative approach and descriptive type of research because it tries to describe the existing conditions in the field which is the process of community empowerment through local institutions in disaster affected communities. This research was conducted in Paguyuban Kampung Sablon, precisely in Wedi Village, Klaten, Central Java during MaySeptember 2017. In this study, data was collected by observation, documentation, and interview and analyzed by descriptive approach.

\section{RESULTS AND DISCUSSION}

Paguyuban Kampung Sablon is a non-partisan, independent and non-profit organization based on membership in home industry community and convection workers in Krangkungan Pandes hamlet, Wedi Klaten. Paguyuban Kampung Sablon started its activities in August 2006 and officially declared to be founded when five of home industry owners of convection hold a meeting on October 7, 2006.

The establishment of Paguyuban Kampung Sablon derived from the will to rise again and become independent after the disaster in 2006. Originally, the beginning of this Sablon Village was established in 2006. "Formerly, there were a lot of convection business here, but it was more individually run. However, after the disaster, many business capitals were destroyed. Some of them has nothing left, some of them only has sewing machine remains, and some of them only has silk screening, really, there was not much left. Before the disaster, we were quite close to each other and often hanging out together, that's what we called it. Therefore, right after the disaster, we immediately discussed about what we can do for the next. Then it sparked the idea to establish the society of this Sablon Village. So, the aim of it is to collect convection entrepreneurs here whose business capital only has little remains, so we can help each other. For example, the A who has a sewing machine, he gets the sewing part. The B who has a silk-screening tool, he will get the part to silk screen it. Later, there is a marketing section. Right after the disaster we didn't really felt down so soon, because we feel like we have friends and we can help each other. After the establishment of Paguyuban Kampung Sablon, we promoted it everywhere. Praise the lord, we got many orders maybe it's also because they see our condition" (FX, member of Paguyuban Kampung Sablon).

The establishment of Paguyuban Kampung Sablon as a local organization in the community of Wedi village gave many benefits, both for members of Paguyuban Kampung Sablon and for the surrounding community. This is as expressed by the members; the benefits are great. "For example, initially there are 3 orders, but in this association, we get more, maybe like 4 or 5 . At first, the marketing is still conventional, maybe only to schools friend and so. Then we are in the Village Sablon knew about IT a little bit, so that time we conducted marketing through FB" (AB, member of KS). It was revealed that members of Kampong Sablon members benefited by the presence of Paguyuban Kampung Sablon, which expanded the business marketing of members, facilitated the marketing of member's business through various social media, boosting the name of Wedi Village and convection business.

Apart from providing benefits for the community itself, the surrounding part of the society also receive benefits by the presence of Paguyuban Kampung Sablon, especially young people who get jobs as well as experience by joining one of the member. "Yes, there is a benefit for the society, such giving vacancies for surrounding community. Like me who work at Mas Heri. Other young villagers are also attracted to the convection business. Some are still attend school, some are already graduated. It's great, it can give me some more income" (LS, Wedi villagers). There are also some people who began to open small-scale convection business themselves after joining the business of one of the members of the Village Circle Sablon. This is expressed by IND, a member of Paguyuban Kampung Sablon, "There are some people who used to work for me, but now they have started their own business so they don't work here anymore. So, there are some people who work here before, then because they felt like they already have the knowledge and experience, finally they open their own business. And we even think that it was great, because they can start their own now".

Based on the findings in the field, the findings should conduct socio-economic change under the term of community turned out to be fruitful in the development of Wedi Village as a whole. It was found that the presence of Paguyuban Kampung Sablon as a local institution has benefited the management of selfdevelopment community. There are several advantages of this institution according to Soetomo (2013), namely; the institution is quite entrenched in society, so that its existence is stronger and well established and have wider support from the community itself; this institution has been more tested because it is obtained through the learning process in responding to the development of environment both natural environment and social environment; and this institution further guarantees the sustainability of joint activity patterns. This is proven by the benefits of development felt by small entrepreneurs' members of the community and the other community as well.

However, the presence of Paguyuban Kampung Sablon as community-based inititative also has some weaknesses. Almost all members of Paguyuban Kampung Sablon stated that, "We never get fund or empowerment program from both government and other institutions. We just got money for building our basecamp once. Many proposals have been spreaded but we got nothing. We only get fund from SBY's program after disaster named soft loan (KUR) amounted 5 million Rupiah. But we kept paying it back." This condition has been explained by a recent review of IFRC (2003) on Messer (2003) finds that: “..., the main weakness of community-based initiatives is their limited outreach. Scaling up to achieve greater impact needs the 
participation of government. Yet the state and its apparatus are often seen as part of the problem". The study held by Masser on other local institutions in disaster-affected area shows that the coordination between community-based initiative organisations and government sometimes run unproperly. As stated by the member of community above, even though Paguyuban Kampun Sablon is well-known enough as disaster-affected entrepreneurs' community, but they rarely get fund and empowerment program. Accordingly, this local institution run their activities by members only.

One key point from this research is local institutions for disaster-affected entrepreneurs really needs greater coordination to greater authorities. Establishment of communication mechanisms and information exchange among local institutions is to ensure greater coordination. The main weakness of local institution as community-based initiative is its lack of coordination. Therefore, communication and coordination are the main concerns. Besides, strengthening the organizational capacity of local organizations should also be the attention.

\section{IV.CONCLUSION}

From the research results it can be concluded that the presence of local institutions has a very important role in recovering the socio-economic conditions of the affected communities, especially in members of Paguyuban Kampung Sablon. Local institutions that stand on the initiative of citizens are able to grow and empower other community so that the process of economic and social development in Wedi Village can run well after the disaster. However, the coordination, communication, and organizational skill should be improved well.

\section{REFERENCES}

[1] I.R. Adi. Social Welfare Science and Social Work (Ilmu Kesejahteraan Sosial dan Pekerjaan Sosial), Depok : FISIP UI Press. 2005

[2] I.R. Adi. Community-Based Participatory Planning: From Thought to Application (Perencanaan Partisipatoris Berbasis Aset Komunitas:Dari Pemikiran Menuju Penerapan), Depok : FISIP UI Press. 2017

[3] I.R. Adi, Isbandi Rukminto, Community Intervention \& Community Development as an Effort for Community Empowerment (Intervensi Komunitas \& Pengembangan Masyarakat Sebagai Upaya Pemberdayaan Masyarakat), Jakarta : PT.RajaGrafindo Persada. 2014

[4] A.M. Amien. Local Independence: Development, Organizational, and Education Concepts from a New Science Perspective (Kemandirian Lokal : Konsepsi Pembangunan, Organisasi, dan Pendidikan dari Perspektif Sains Baru) Jakarta : PT. Gramedia Pustaka Utama. 2005

[5] O.M. Anwas. Community Empowerment in the Global Era (Pemberdayaan Masyarakat di Era Global). Bandung : Penerbit Alfabeta. 2013

[6] Asian Disaster Preparedness Center, (2008), Community Empowerment and Disaster Risk Reduct $b$ ion in Chittagong City, Bangladesh Government.

[7] A.H.Besar; A. Hari; M. Y. Batubata and Margono, (Community Empowerment 'Victims of Lapindo Mud' in Ensuring the Survival of Live in Mindi Village, Porong Sub-district, Sidoarjo Regency) Pemberdayaan Masyarakat 'Korban Lumpur Lapindo' dalam Menjamin Keberlanjutan Hidup (Survival of Live) di Desa Mindi, Kecamatan Porong, Kabupaten Sidoarjo, Malang : Universitas Negeri Malang. 2014

[8] D.P. Coppola. Introduction to International Disaster Management. USA : Butterworth-Heinemann. 2006

[9] Department of Public Works of the Directorate General of Human Settlements. Special Module for Facilitator: Disaster Management and Management (Departemen Pekerjaan Umum Direktorat Jenderal Cipta Karya. Modul Khusus Fasilitator : Pengelolaan dan Penanganan Bencana) PNPM Mandiri Kota. 2007

[10] C. Johansson and M. Linell. Public Empowerment Policies for Crisis Management, Mid Sweden University. 2014

[11] S.Kenny. Developing Communities for The Future, 3rd edition, Melbourne: Thomson. 2007

[12] R.J.Kodoatie and R. Sjarief, Integrated Disaster Management;Flood, Landslide, Drought, and Tsunami (Pengelolaan Bencana Terpadu;Banjir, Longsor, Kekeringan, dan Tsunami), Jakarta : Yarsif Watampone. 2006

[13] A.Kreimer and M. Arnold. Managing Disaster Risk in Emerging Economic,. USA : The World Bank. 2000

[14] H. Kunreutcher and M. Useem. Learning from Catastrophes : Strategies for Reaction and Response, USA : Pearson Education. 2010

[15] J.Lassa; P. Pujiono; D. Pristiyanto. Community Based Disaster Risk Management (Pengelolaan Resiko Bencana Berbasis Komunitas). Jakarta : PT Gramedia Widiasarana Indonesia. 2009

[16] Lismana; R. Widya. Analysis of Socio-Economic Empowerment Program Post-Disaster in Pasir Village Mempawah District (Analisis Program Pemberdayaan Sosial Ekonomi Pasca Bencana di Desa Pasir Kabupaten Mempawah), Jurnal S1 Ilmu Pemerintahan Volume 4 Nomor 3 Edisi September 2015 Pontianak: Universitas Tanjungpura Kalimantan Barat. 2015

[17] Marshall, Catherine dan Gretchen B.Rossman. Designing Qualitative Research, USA: Sage Publications. 2006

[18] N.M. Masser. The Role of Local Institutions and their Interaction in Disaster Risk Mitigation: a Literature Review, September 2003.

[19] Z. Matsimbe. The Role Of Local Institutions In Reducing Vulnerability To Recurrent Natural Disasters, October 2003.

[20] J. Midgley. Social Development, The Developmental Perspective in Social Welfare, London : Sage Publication. 1995

[21] Social Development : Theory and Practice, London : Sage Publication. 2014

[22] Naryanto, Heru Sri, (2001), Disaster Management Series LPPS Series No. 43, Jakarta: Institute for Research and Social Development (Penanganan Bencana Seri Forum LPPS No. 43, Jakarta : Lembaga Penelitian dan Pembangunan Sosial) Caritas Indonesia. 2001

[23] I. Nawawi. Development and Community Problems "Study of Concepts, Models, Theories of Economic Aspects and Sociology (Pembangunan dan Problema Masyarakat:Kajian Konsep, Model, Teori dari Aspek Ekonomi dan Sosiologi), Surabaya : Putra Media Nusantara 
[24] W.L.Neuman. Social Research Methods : Qualitative and Quantitative Approaches, USA : Allyn and Bacon. 1997

[25] B. Pandey and K. Okazaki. Community Based Disaster Management : Empowering Communities to Cope With Disaster Risks, Japan : United Nations Centre for Regional Development. 2005

[26] A. Pramono. Development and Community Problems "Study of Concepts, Models, Theories of Economic Aspects and Sociology (Pengembangan Kelembagaan Lokal), Jakarta : Management Studio \& Clinic. 2011

[27] Rajeev. Sustainability and Community Empowerment in Disaster Management. International Journal of Social Work and Human Services Practice Vol.2. No.6 Dec, 2014, pp. 207-212

[28] Soetomo. Community Development: Constructing a Framework (Pembangunan Masyarakat : Merangkai Sebuah Kerangka), Yogyakarta : Pustaka Pelajar. 2009 , Community Empowerment: Could It Be An Antithesis Pemberdayaan Masyarakat : Mungkinkah Muncul Antitesisnya?, Yogyakarta : Pustaka Pelajar. 2013

[30] E. Suharto. Building People, Empowering People (Strategic Review of Social Welfare Development \& Social Work (Membangun Masyarakat, Memberdayakan Rakyat ; Kajian Strategis Pembangunan Kesejahteraan Sosial \& Pekerjaan Sosial), Bandung : PT.Refika Aditama. 2005
[31] G. Sumodiningrat. Social Empowerment A Brief Review of Indonesia's Human Development Pemberdayaan Sosial Kajian Ringkas Tentang Pembangunan Manusia Indonesia, Jakarta: Penerbit Buku Kompas. 2007

[32] Warto, et. al. Assessment of Disaster Management Management for Communities in Disaster Prone Areas in the Era of Regional Autonomy (Pengkajian Manajemen Penanggulangan Korban Bencana pada Masyarakat di Daerah Rawan Bencana Alam dalam Era Otonomi Daerah), Yogyakarta : Balai Besar Penelitian dan Pengembangan Pelayanan Kesejahteraan Sosial (Center for Research and Development of Social Welfare Services). 2002

[33] R. Wrihatnolo and R. N. Dwidjowijoto. Empowerment Management An Introduction and Guide For Community Empowerment (Manajemen Pemberdayaan Sebuah Pengantar dan Panduan Untuk Pemberdayaan Masyarakat), Jakarta : PT. Gramedia. 2007

[34] Yustiningrum and R. R.Emilia, Strategies for PostNatural Disaster Handling in Indonesia: Impact on Rural Groups (Strategi Penanganan Pasca Bencana Alam di Indonesia : Dampak Terhadap Kelompok Rentan), Jakarta : LIPI. 2010 